Four years ago Merryn Philpott, the local Territory Health Services speech pathologist, began collaborating with KRALC's linguists and language workers to develop culturally and linguistically appropriate assessment tools for the mainly Kriol speaking people of the region. KRALC began training interpreters in Kriol and English. These interpreters provided a critical role in checking and revising the tools, which are based on observation and anecdote by the linguists, and not on research.

Merryn worked with linguists Prudy McLoughlin and Denise Angelo and interpreters Anne Marie Huddleston and Barbara Raymond to produce the revised information. Prudy said, We were using material that had been developed in England which had absolutely no relevance to Aboriginal children. So we modified the tests so that children could understand them, which allowed us to gain a real appreciation of the problems they were facing.'

The team returned to the communities with the revised material. They began making the weeklong trips to the bush visiting children with speech difficulties and their parents. Prudy said:

The work has been worthwhile. The children could immediately identify with what was being asked of them and we were able to assess them

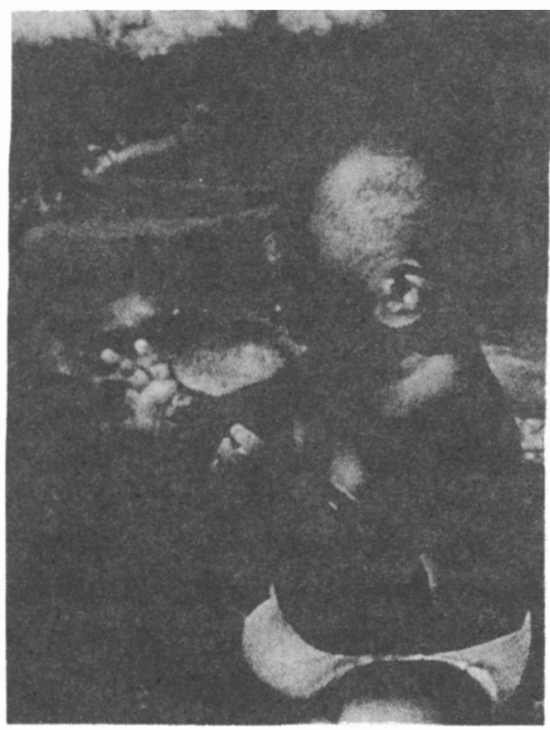

immediately and accurately. The interpreters were invaluable in helping me to communicate with the parents of children with cleft palates. We are able to discuss future operations on the children, and go through the different therapy programs which are available.
In recognition of its work in breaking down communication barriers, the Centre received the 1997 national Community Contribution Award from Speech Pathology Australia. National president of Speech Pathology Australia, Ms Ann Burton, said, 'The Centre's achievements in a short space of time demonstrate the need for skilled people to come together to tease out problems and come up with workable and affordable solutions.' She added that:

Children with communication disabilities often experience associated difficulties leading to poor literacy skills and low academic achievements. Many people with a communication disability are subject to prejudice. They may be ignored, their ideas and opinions not asked for. The results are frequently frustration and anger. The Centre's work goes a long way to make sure that Aboriginal children of today and tomorrow will be protected from such taunts.

Editor's note: This item first appeared in ATSIC News Winter 1997, p. 6. We wish to thank the Aboriginal and Torres Strait Islander Commission's Office of Public Affairs for allowing us to reprint it here.

\section{Olympic Hopeful Lifts his Students}

Aboriginal teacher-aide, Anthony Martin, is well on his way to achieving his goal of representing Australia in weightlifting at the 2000 Olympics, after ranking ninth at the junior world championships in South Africa last month.

Weighing in at $125 \mathrm{~kg}$, the 18-year-old former Rosewood State High School student and current teacher-aide has come a long way since he first decided to lift weights barely three years ago. He began training in Ipswich at the Police Citizens Youth Club and now travels for over two hours, five nights a week to the Chandler sporting complex near Brisbane's bayside, for two and a half hour long sessions with former Olympian Michael Keelan.

$\mathrm{Mr}$ Keelan is a retired weightlifter who represented England and decided to stay after the 1982 Commonwealth Games. He is now Mr. Martin's coach, trainer and mentor.

'T'm thinking of building a shed in the backyard so I can train three days at home and not have to 
travel as far - my main goal is to get to the Olympics,' Mr Martin said. He currently competes in the under-20, 108-plus kilo division and is the Australian under-18 and under-20 record holder; Commonwealth under-18 record holder; and 1996 under-18 and under-20 Australian champion.

Weightlifting has taken Mr Martin from his home in Rosewood to many cities and countries around the world. He has competed nationally in Melbourne, Adelaide and Perth, and internationally in Austria, Malaysia, England, New Zealand and most recently Cape Town in South Africa.

Fellow Rosewood High aide Kaye Martin, no relation, said Mr Martin's ninth placing in the world under-20 108kg-plus category was a remarkable performance. 'Not bad going for an 18year-old who had not even considered the sport three and a half years ago,' Ms Martin said.

The result was part of his personal plan to achieve his dream, as he wanted to come in the top 10 at this competition. This former pupil has come back as an aide to Aboriginal and Torres Strait Islander students, and is proving to be an ideal model for all our students.

Mr Martin is of Aboriginal heritage, originally from the Kimberleys in Western Australia.

'He has a great rapport with young people, and in his quietly-spoken manner he has made an impact on both staff and students at Rosewood,' Ms Martin said. 'Anthony has a strong wish to encourage school children to make the most of their abilities and achieve the best they can for themselves'.

Mr Martin has a busy schedule ahead with several national meets. The Australian titles are on in Adelaide this week, with the under-20 and open division competition in Sydney in October, before the Trans-Tasman Challenge in Adelaide in December.

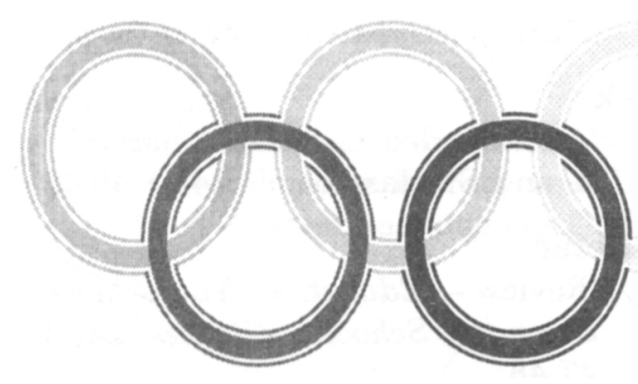

Section F - News
Mr Martin said there was also a possibility of attending three other international events later in the year - in Austria, Colorado and China, through sponsorship from the Australian Weightlifting Association.

Editor's note: This article first appeared in Education Views, July 4, 1997, p. 28 and is reprinted with permission of the Public and Media Relations Branch of the Queensland Department of Education. $\square$

\section{Education for Self-Determination. Review of RCIADIC Recom- mendations Regarding Aboriginal Community Controlled Adult Education}

In August the Federation of Independent Aboriginal Education Providers completed a project under the Australian Institute of Aboriginal and Torres Strait IslanderStudies (AIATSIS) commissioned research program. The project reviewed the implementation of the Royal Commission into Aboriginal Deaths in Custody recommendations as they applied to the policies and practice of governments in relation to their sector.

The project identified a total of 33 relevant recommendations, analysed current national policy and documented the perceptions of the six independent colleges which the Federation represents. A national workshop was held at AIATSIS in June 1997 which brought together representatives from the Federation and some researchers working in the field. The project report, Education for Self-Determination, is now available from the Federation or through the AIATSIS Library. Papers from the workshop will be published later this year in the AIATSIS Discussion Paper Series.

For further information please contact the FIAEP Secretariat, P.O. Box 308, Jamison Centre ACT 2614. Phone: (02) 6247 5747, Fax: (02) 6251 7935, e-mail bob.baaace@netinfo.com.au. Information about the FIAEP is also available through its website at:

http://www.koori.usyd.edu.au/fiaep. 